\title{
Implications of Indian Foresters' Perspectives of Joint Forest Management
}

\author{
Kamal Kishor Sood · Hemant Kumar Gupta
}

Received: 19 June 2007 / Accepted: 19 June 2007

(C) Steve Harrison, John Herbohn 2007

\begin{abstract}
A study was conducted in Kullu district in the province of Himachal Pradesh in Indian Western Himalaya, to investigate the perceptions of Indian foresters about aspects of forest management relevant for effective Joint Forest Management (JFM). A lack of uniform understanding was found amongst forestry staff about almost all the studied issues pertaining to JFM. A need is identified to emphasise social aspects in the training of the foresters (including in-service training), along with the existing silvi-technical aspects. For JFM success, measures need to be devised to reduce the political interference in JFM, reduce hierarchical rigidity, and increase interaction between field staff and the administrative hierarchy. Strategies should be devised to make JFM participants as well as forestry staff equally responsible to honour their commitments with respect to JFM.
\end{abstract}

Keywords Himachal Pradesh · Forest act · Caste · Forest guards · Professional training

\section{Introduction}

The basic structures to manage the various types of land use in most developing countries originated from temperate Europe and North America (Lundgren 1987). The modernisation of agriculture and forestry in the late 19th century was driven by revenue-earning motives and industrialisation. This led to the gradual emergence of institutions to support the land users. Relative to agricultural production which was

\footnotetext{
K. K. Sood $(\bowtie)$

Division of Agroforestry, Faculty of Agriculture, Sher-e-Kashmir University of Agricultural Sciences and Technology, Main Campus-Chatha, Jammu 180009 Jammu and Kashmir, India e-mail: kksood_2000_2000@yahoo.com
}

H. K. Gupta

Forest Survey of India, North Zone, Shimla, India 
managed mainly by the farmers, industrial wood production (which was carried out on separate types of land) required different professional skills, had different aims and was often managed by government. Therefore, it was entirely rational that forestry institutions developed independently of agricultural institutions (Lundgren 1987).

British in India assumed that local people, who had their own decentralised system of forest management, were responsible for forest degradation. Thus the Indian State Forest Department (FD) was established in 1864 during the British regime to deal with management and protection of the State forests (Hobley 1996). Independent India inherited this forest administration structure from British which has changed little since its inception. This centralised system was in conformity with the colonial government's requirements of policing the forests and earning revenue (Dalal 1992). The system is characterised by a bureaucratic ethos, with hierarchical rigidity, centralised powers, non-participatory decision-making, and organisational and procedural rigidity (Kumar and Kant 2005).

Datta and Ray (1996) and Saxena (2000) observed that training at the forest academy, forest colleges and schools in the Indian provinces is based on a curriculum that has changed little in the last 100 years. This training has been oriented towards learning silvi-technical concepts of forestry to raise trees for timber, rather than social skills. During the same period, the development of the forest administration and forestry practice has witnessed many shifts in sociopolitical perceptions towards forests and the public forest service. These shifts in forestry practices vary from the initial surveying and demarcation of forest lands to the policing role to the introduction of Joint Forest Management (JFM).

The introduction of JFM has required development of complex skills associated with management of interactions of people with resources (Poffenberger 1990a; Saxena 1995). Forestry bureaucrats perceived that the problem of forest degradation is caused by uncontrolled use of the forests by the villagers. Thus State control for protecting the forests was introduced in various parts of the world in the early 19th century. State-imposed rules, regulations and restrictions on forest use through FD in India up to the late 1970s, especially for commercial and industrial purpose, alienated the local communities from the forests. They also created an antagonistic relationship between the FD and forest fringe communities (Matta et al. 2005). Further, it was felt difficult to protect the vast and scattered forests from the local communities due to lack of manpower and finance in the FD. The success of the Arabari (West Bengal) and Sukho Majri experiences of JFM in 1980s showed the potential of people's participation or co-management of forests in successful afforestation and forest management (Malhotra and Poffenberger 1990; Dhar 1994), and the concept of JFM gained impetus. Forestry and forest management have been affected by development strategies evolved in wider fields of development policy since Hobley (1996) examined the emergence of co-management or joint management of forests linked to international events from the 1970s onwards (Table 1).

Co-management has been now recognised as a fundamental aspect of natural resource management (Pretty 2003). JFM is the sharing of products, responsibilities, control and decision-making authority over forest lands between the FD 
Table 1 Typology of change in forest management practices

\begin{tabular}{|c|c|c|}
\hline Decade & Event & Response \\
\hline 1970 s & $\begin{array}{l}\text { Oil crisis } \rightarrow \text { other energy crisis, } \\
\quad \text { fuelwood crisis } \\
\text { Sahelian drought } \rightarrow \text { deforestation } \\
\text { Bangladesh flooding } \rightarrow \\
\quad \text { deforestation }\end{array}$ & Afforestation to meet fuelwood needs of people \\
\hline $1980 \mathrm{~s}$ & Eco-disaster $\rightarrow$ forestry renaissance & $\begin{array}{l}\text { Social forestry and agroforestry } \\
\text { Creation of new forest resources (woodlots) } \\
\text { Focus on afforestation } \\
\text { Focus on fuelwood, not on food and income } \\
\text { supplies }\end{array}$ \\
\hline Late $1980 \mathrm{~s}$ & $\begin{array}{l}\text { Changing development } \\
\text { practice } \rightarrow \text { from top-down } \\
\text { to bottom-up planning }\end{array}$ & $\begin{array}{l}\text { Participation } \\
\text { Value of indigenous knowledge } \\
\text { Enhanced role of Non-governmental } \\
\text { Organisations }\end{array}$ \\
\hline 1990s onwards & $\begin{array}{l}\text { New forest sector policies } \\
\text { Rio Declaration and Agenda } 21 \\
\text { Decentralisation of decision- } \\
\text { making } \\
\text { Public sector reform in World } \\
\text { Forestry }\end{array}$ & $\begin{array}{l}\text { Co-management or joint forest management } \\
\text { Public sector reform in World Forestry } \\
\text { Policy and institutional reform, new } \\
\text { partnerships } \\
\text { Forestry for multiple objectives, multiple } \\
\text { stakeholders, multiple partnerships } \\
\text { Participatory shared or joint forest } \\
\text { management }\end{array}$ \\
\hline
\end{tabular}

Source: Modified from: Hobley (1996)

and local user groups under a formal agreement. This can be depicted as a form of power sharing between the State and a community of resource users (Berkes et al. 1991; Carlsson and Berkes 2005). JFM requires FDs to move beyond simply seeking local community input in developing forest management plans, to actually working with the communities to manage the forests on a day-to-day basis. This would also require a shift in attitude of foresters from 'protecting the forests from people' to 'protecting with people' (Matta et al. 2005). The key feature in JFM is the establishment of grassroot community institutions for protecting and managing forests on the basis of the 'care and share' principle. JFM places the forest users at the centre of the management process and builds an appropriate local level institution capable of managing and protecting the forest resources (Hobley 1996).

Interactions between foresters and rural populations have been limited in the past to protection, policing and revenue collection (Falconer 1987). Established hierarchies favour a top-down approach due to the historic role of forest services as the 'resource cops' in addition to the superior attitudes engendered by their 
professional training (Falconer 1987; Shaikh 2000). The success of JFM strategies then is dependent on the manner in which this philosophy is embraced by field-level staff. This process involves a substantial shift in organisational culture, away from a top-down hierarchical rigidity, centralised and non-participatory decision-making and conservative technically-oriented FD, and towards flexible, people-centred, learning-oriented strategic organisations (Thomson 1995). The success of JFM depends on mutual understanding between the FD and local communities. During the transition to a new paradigm, forestry planners have assumed a congruence between the bureaucratic set-up of the FD and the decentralised ethos of JFM, which may or may not be true (Kumar and Kant 2005). In such a situation, the role of the perceptions of the foresters is pivotal for successful implementation of JFM.

Little is known about foresters' perspectives of rural people and forest management (Dove 1992; Matta et al. 2005). Therefore, the perceptions and views of the forestry staff towards JFM warrant empirical investigation to identify strategies for effective JFM. Further, the hierarchical administrative structure of FD restricts procedural and policy decision-making to only the most senior officials at the provincial or national level. However, the implementation of new strategies takes place at the lowest level of the hierarchy and it is here that policies are adjusted to the realities of the local situation. It is necessary to investigate perceptions of these field foresters because these are the members who interact frequently with the villagers, the clients of the FD in JFM, and influence the way in which a community regards the forest bureaucracy (Poffenberger 1990b).

The present study in the district Kullu of Himachal Pradesh (India) elicits foresters' perception on:

- the role of people's participation in forest management;

- possible causes for success and failure of JFM;

- villagers' awareness concerning forest degradation and the need for forest improvement;

- impediments in preparation and execution of JFM plans;

- the need for in-service training for effective JFM;

- forest management constraints, modification of existing laws and rules pertaining to forest management, and the need for change in the practice of granting timber allocations at concession rates to the people; and

- the effect of implementation of JFM on the traditional discipline of the FD.

The next section reviews the organisation of the Indian FD and the mode of operation of JFM in India. The study area is then defined, and the research method outlined. This is followed by presentation of survey findings, discussion of these findings, and the drawing of conclusions and formulation of strategies to enable effective JFM.

\section{Organisation of the Indian Forest Department and Mode of Operation of JFM}

The hierarchy of forest organisation in India is illustrated in Fig. 1. Forest Guards, Deputy Rangers and Rangers constitute the non-gazetted ranks whilst the Assistant 


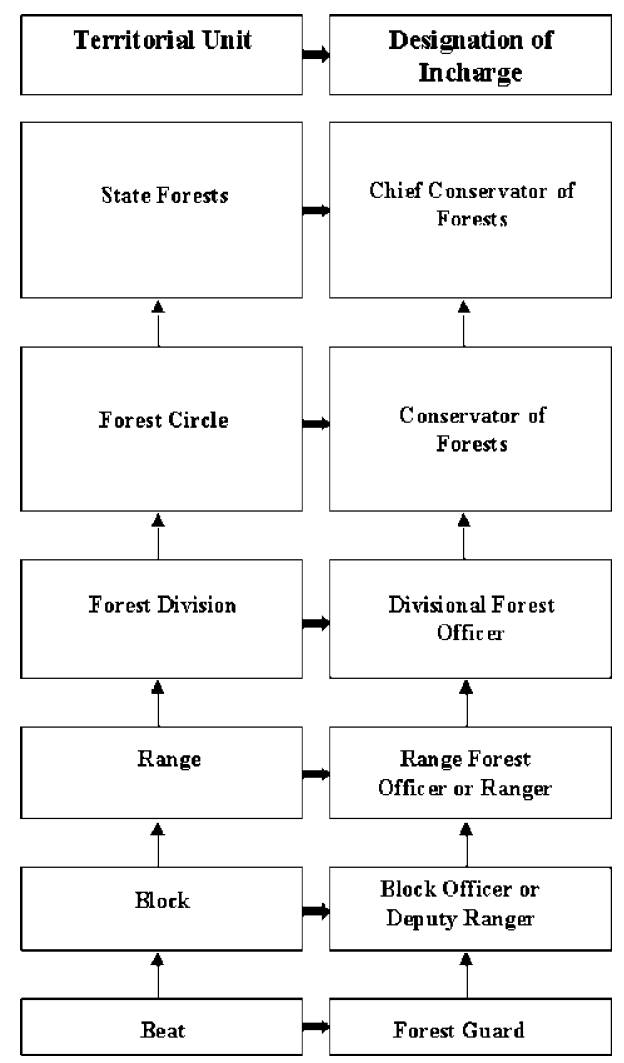

Fig. 1 Hierarchy of forest organisation in India. Source: Gupta (1999)

Conservator of Forests upwards are gazetted Forest Administrators. The nongazetted cadre are obliged to wear uniforms concomitant with their policing role in the control of movement of forest produce and implementation of the provisions of the Indian Forest Act, 1927. India has one of the largest professional forest services in the world, with more than 150,000 foresters serving in various cadres (Poffenberger 1990a).

The introduction and development of JFM entails the formation of institutions known as Village Forest Development Committee (VFDCs) or Forest Protection Committees (FPCs) which organises user groups to protect, manage and develop forest areas. A forest official, normally the Forest Guard, is usually the secretary of the Executive Committee of VFDC for deciding various matters pertaining to JFM.

The forest guards are conduits for the flow of information within the system. They co-ordinate all inputs to villages and act as an interface between villagers and the FD. The duties of forest guards with regard to implementing JFM in addition to regular duties are to: 1 . establish effective and representative VFDCs; 2. maintain contact with JFM participants; 3. provide technical advice to JFM participants; 4. arbitrate between sub-groups when requested if conflicts arise; 5. collect information through Participatory Rural Appraisal; 6. provide technical and social feedback 
to the Joint Forest Management Support Team (JFMST) of FD; 7. facilitate project activities at village level to include joint management and farm forestry where appropriate; and 8. facilitate the full participation of woman and poor people in JFM activities and liaise between villagers and the FD (ODA 1994; Wee and Jackson 1994).

JFM is a community-based approach where all the households in a village are recognised as users of the surrounding forests. In order that forest management intervention succeeds it must cater for the needs of the individual households and, therefore, the participation of all the households is necessary.

\section{The Study Area}

The study was carried in Kullu district of the Indian province (state) of Himachal Pradesh located in the Western Himalayan (Fig. 2).

There are 12 districts in the province of Himachal Pradesh, and Kullu district was purposely chosen for the study because it was the first district in the province to implement JFM in project mode in co-ordination with the Department for International Funding (DFID), UK. The objectives of implementation of JFM in

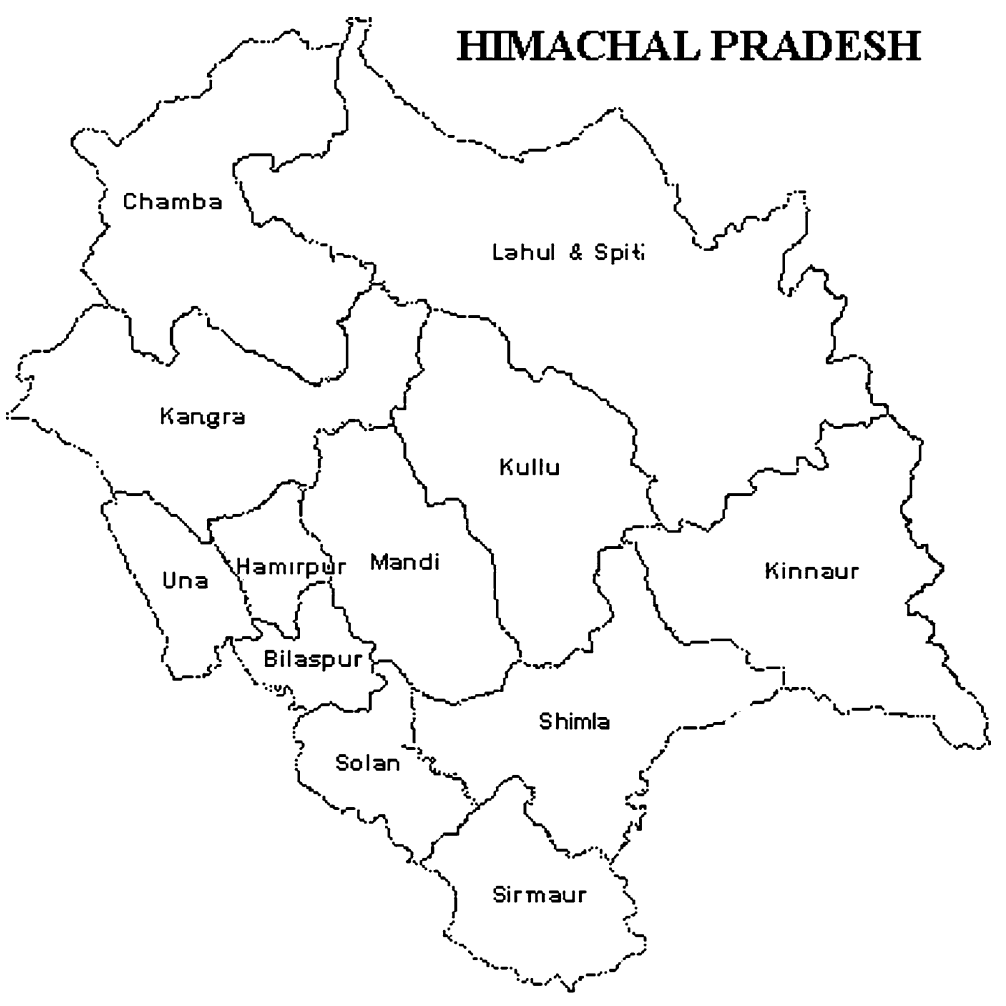

Fig. 2 Location of Kullu district within province of Himachal Pradesh. Source: GOHP (1993) 
Himachal Pradesh are development and protection of forests and sharing of benefits derived from JFM. Kulla district is predominantly mountainous, with land rising steeply from streams in the narrow valleys. The altitude varies from 1,283 $\mathrm{m}$ to about 6,495 $\mathrm{m}$ above mean sea level. The rainfall is highest during July to September, but with a second peak in December to February, with mean annual rainfall of $1,500 \mathrm{~mm}$. The mean monthly temperature of the district is $28^{\circ} \mathrm{C}$ (GOHP 1993).

The total population of Kullu district was 302,432 in 1991, this being $5.9 \%$ of the population of province of Himachal Pradesh (GOHP 1993). Population density is relatively low at 55 person $/ \mathrm{km}^{2}$, in comparison to the Himachal Pradesh provincial average of 92 persons $/ \mathrm{km}^{2}$. Most of the population in the district is Hindu, with social structure dominated by the hierarchy of four varnas (castes). Brahmins form the highest caste, Khatriyas and Vaishyas the middle castes, and Shudras the lowest caste. Castes as social groups are held together by internal and external forces. The internal forces that bind members of a caste into a well-organised and stable group include restrictions placed upon the members with regard to eating, drinking and marriage, as well as common occupations, customs and traditions (Anant 1972). The relatively closed nature of the caste groups as an external force discourages any attempt on the members of other castes to aspire for status in these groups.

The total land area of Kullu district is $5,503 \mathrm{~km}^{2}$ with a classified forest area of $5,000 \mathrm{~km}^{2}$ (GOHP 1993). Of the area classified as forests, only $35.4 \%$ is actually under tree cover and the remainder is grassland, shrubs and bushes. Forests occur at all elevations between $1,263 \mathrm{~m}$ and $3,700 \mathrm{~m}$. For forest management and administration purpose, Kullu district has been organised into three territorial forest divisions-Kullu, Parbati and Seraj-which are constituents of the Kullu Forest circle. People of Kullu have recorded rights on the forests. In forest settlements in the district, people can exercise two types of rights regarding access and use of various categories or classes of forests, namely rights with permission of the FD and rights without permission, the latter being known as 'Concessions'. Rights to the following forest products and services have been recognised (Gupta 1999, unpublished):

1. Timber for building purposes

2. Grazing of cattle, sheep and goats

3. Grass and leaves for fodder

4. Agriculture and domestic implements

5. Fuelwood for domestic use from dry and fallen twigs

6. Fuel, torches, charcoal, wood for funeral purposes

7. Manure

8. Medicinal and aromatic herbs, honey and small bamboo.

All the above rights are restricted to domestic use, with the exception of the right to medicinal and aromatic herbs which can be sold with income from such sales benefiting individual right-holders. Few or no rights are permitted within reserved forests. Access to timber in Kullu (as elsewhere in Himachal Pradesh) is known as the Timber Distribution (TD) right. TD rights are exercised by local people on payment of very low fees to the FD, with rates fixed by the State at the time of forest 
settlement. Household access to timber is sanctioned by the FD every 5 years, but with more immediate access in the case of exigencies such as when houses are destroyed by fire.

\section{Research Method}

Informal discussions were held with key informants from the local population as well as forestry staff from the study area, to obtain a general impression of the issues pertaining to forests and forest management. A questionnaire (described by Gupta 1999, unpublished) was then prepared to elicit perceptions and views of the forestry staff $^{1}$ towards JFM. The questionnaire contained a mixture of closed and openended questions. The questionnaire was finalised after discussion with the JFMST, Kullu, during divisional level workshops held under the Himachal Pradesh Forestry Project. Personal interviews were conducted by the authors. The respondents consisted of Forest Guards (FG) (30), Deputy Rangers (DR) (12), Forest Rangers (FR) (12), and Assistant Conservator of Forests (ACF) and higher ranks (6), a total sample size of 60. Provincial government guidelines and notifications with respect to JFM were also reviewed. Some qualitative information was collected through informal discussions with FD staff on various aspects of JFM and to elicit reasons of holding their perceptions on JFM. This was augmented by the second author's 15 years experience of work in the State FD.

Data analysis was undertaken using SPSS ver. 10 for Windows. It was assumed that responses of forestry staff would be uniformly distributed across different response categories because all of them follow the same procedures, rules and regulations of forest management and JFM. Chi-squared goodness-of-fit tests were used to examine whether responses of forestry staff differed across the various response categories, at the $5 \%$ significance level.

The response categories chosen for factors of success and failure of JFM were: AG: Agree, ASE: Agree to some extent; CS: Can't say and DA: Disagree. The methodology of Reddy et al. (1999) was used to rank the various response categories. This involved assigning importance weights to response categories in descending order of importance (AG: 4, ASE: 3, CS: 2, and DA: 1). For each question, the number of respondents assigning each particular importance level were multiplied by the corresponding weights and these were summed to obtain the total score.

\section{Research Findings}

Distributions of age and work experience of respondents are reported in Tables 2 and 3 respectively. About $63.3 \%$ of the foresters were of age less than 40 years.

\footnotetext{
1 The terms 'foresters' and 'forestry staff' are used synonymously and include those personnel of the Forest Department who have undertaken specialised forestry training in various forestry schools and colleges in India. For the present study, foresters encompassed forest guards, deputy rangers, range forest officers and divisional forest officers.
} 
Table 2 Age distribution of forestry staff

\begin{tabular}{lc}
\hline Age class & No. of individuals \\
\hline$<30$ years & 5 \\
$31-40$ years & 33 \\
$41-50$ years & 7 \\
51 years and above & 15 \\
\hline
\end{tabular}

Nearly $80 \%$ had worked with the FD for at least a decade. Of the FGs and DRs, 12 had training with a JFM support team, 25 had received training with the Overseas Development Agency of the UK (ODA) within India, 17 FG and DR had training in provincial forestry schools, and 5 FG and DR had no formal training. Twenty-four had travelled outside the province, 8 within the province, 7 (ACF and above, and one FR) overseas, and 21 had no travelling related to the JFM program. Additionally, informal discussions with foresters revealed heterogeneity with respect to their socio-economic circumstances.

\section{Perceptions on Training and Project Support for JFM}

Most forestry staff (93\%) felt that there is a need for specialised training to support the JFM program. They also identified a need for project support for extended program implementation until JFM procedures become an integral part of departmental functions.

\section{Factors for Success and Management Constraints for JFM}

The responses of forestry staff about possible factors of success for JFM for each variable are placed into four categories, as in Table 4. The following hypotheses have been tested: ${ }^{2}$

$\mathrm{H}_{0}$ : The responses of forestry staff are uniformly distributed between response categories (AG, ASE, CS and DA) for each response variable (factor for success). $\mathrm{H}_{1}$ : The responses of forestry staff are not uniformly distributed between response categories for each response variable.

The $\chi^{2}$ values allow the null hypotheses to be rejected in all cases and lead to the conclusion that the distribution of the views between forestry staff is not uniformly oriented across importance categories. Based on scores, 'depletion of forest resource' is considered by foresters to be the most important factor for achieving successful implementation of the JFM, followed by 'availability of land for plantations' (Table 4). These are followed by 'granted rights of forest use', 'provision of addition source of income' and 'employment opportunities' respectively. This is in conformity with the views reported by Sharma (1995). The factors

\footnotetext{
${ }^{2}$ While the data are essentially from the population of foresters in Kullu, the respondents can be considered as a sample in that Kullu is representative of other districts in the province. In this context, the use of a statistical inference technique is valid.
} 
Table 3 Distribution of period of work experience the Forest Department

\begin{tabular}{lc}
\hline Period of experience & No. of individuals \\
\hline 0-10 years & 13 \\
$11-20$ years & 27 \\
21-30 years & 6 \\
$>30$ years & 14 \\
\hline
\end{tabular}

Table 4 Responses of foresters about factors for success of JFM

\begin{tabular}{|c|c|c|c|c|c|c|c|c|}
\hline \multirow[t]{3}{*}{ Factors for success for JFM } & \multicolumn{4}{|c|}{ Response category } & \multirow{2}{*}{\multicolumn{3}{|c|}{$\begin{array}{l}\text { Goodness-of-fit } \\
\text { test }\end{array}$}} & \multirow[t]{3}{*}{ Score } \\
\hline & \multirow{2}{*}{$\begin{array}{l}\mathrm{AG} \\
4\end{array}$} & \multirow{2}{*}{$\begin{array}{l}\text { ASE } \\
3\end{array}$} & \multirow{2}{*}{$\begin{array}{l}\text { CS } \\
2\end{array}$} & \multirow{2}{*}{$\begin{array}{l}\text { DA } \\
1\end{array}$} & & & & \\
\hline & & & & & $\chi^{2}$ & $d f$ & $P$ & \\
\hline Depletion of forest resource & 55 & 5 & 0 & 0 & 41.60 & 1 & $<0.001$ & 235 \\
\hline Availability of land for plantations & 44 & 12 & 0 & 4 & 27.06 & 3 & $<0.001$ & 216 \\
\hline Granted rights of forest use & 42 & 7 & 7 & 4 & 65.20 & 3 & $<0.001$ & 207 \\
\hline Additional source of income & 36 & 16 & 2 & 6 & 46.10 & 3 & $<0.001$ & 202 \\
\hline Employment opportunities & 40 & 4 & 1 & 15 & 62.80 & 3 & $<0.001$ & 189 \\
\hline Homogeneous structure of villages & 25 & 10 & 11 & 14 & 9.460 & 3 & $<0.020$ & 166 \\
\hline $\begin{array}{l}\text { Remote villages (villages more than } 5 \mathrm{~km} \text { from the } \\
\text { nearest road) }\end{array}$ & 22 & 17 & 9 & 12 & 7.70 & 3 & $<0.050$ & 152 \\
\hline
\end{tabular}

considered to be least important for success of JFM are 'homogeneity of structure of the villages' and 'remoteness of the villages'.

The responses of forestry staff concerning reasons for possible failure of JFM are reported in Table 5. The $\chi^{2}$ values allow the null hypotheses to be rejected in all cases except for the variable of 'fatalist attitude', and lead to the conclusion that difference in opinion exist between staff regarding possible factors of failure for JFM (Table 5). 'Communication gap between field staff and top hierarchy of Forest Department' and 'political interference in JFM' ranked as the most important factors considered to lead to failure of JFM. 'Inter-village disputes with regards to implementation of JFM and sharing of the benefits of JFM' is regarded as the third most important factor for possibility of failure of JFM. 'Caste structure' is considered to be least important factor for failure of JFM.

The prioritisation of forest product demand by local communities as perceived by forestry staff as management constraints in JFM are, in order of importance, timber distribution, fodder, fuelwood, grazing areas and non-wood forest products (NWFP) respectively (Table 6). This prioritisation suggests that there is sufficient grazing area available. Thus pressure on the forests for grazing would not be a limiting factor in forest management.

There was a lack of uniformity of opinions of forestry staff regarding how aware the local population are about the level forest degradation and measures needed to improvement forest conditions (Table 7). The $\chi^{2}$ test of goodness-of-fit refutes the null hypothesis of a uniform distribution of the responses amongst response categories (high, medium and low). The highest proportion $(38.3 \%$ ) of forestry staff 
Table 5 Responses of foresters about possible factors for failure of JFM

\begin{tabular}{|c|c|c|c|c|c|c|c|c|}
\hline \multirow[t]{2}{*}{ Reason for failure } & \multicolumn{4}{|c|}{ Response category } & \multicolumn{3}{|c|}{ Goodness-of-fit test } & \multirow[t]{2}{*}{ Score } \\
\hline & $\begin{array}{l}\text { AG } \\
4\end{array}$ & $\begin{array}{l}\text { ASE } \\
3\end{array}$ & $\begin{array}{l}\mathrm{CS} \\
2\end{array}$ & $\begin{array}{l}\text { DA } \\
1\end{array}$ & $\chi^{2}$ & $d f$ & $P$ & \\
\hline Communication gap & 48 & 6 & 2 & 4 & 67.6 & 2 & $<0.001$ & 218 \\
\hline Political interference & 44 & 8 & 3 & 5 & 63.0 & 3 & $<0.001$ & 211 \\
\hline Inter-village disputes & 43 & 9 & 1 & 7 & 39.9 & 2 & $<0.001$ & 208 \\
\hline Composite forest rights & 36 & 14 & 0 & 10 & 19.6 & 2 & $<0.001$ & 196 \\
\hline Illiteracy & 32 & 17 & 0 & 11 & 11.7 & 2 & $<0.002$ & 190 \\
\hline Scarcity of grazing areas & 31 & 7 & 3 & 19 & 32.0 & 3 & $<0.001$ & 170 \\
\hline Non-availability of land for plantations & 29 & 10 & 2 & 19 & 27.06 & 3 & $<0.001$ & 169 \\
\hline Lack of women's participation & 22 & 8 & 4 & 26 & 22.6 & 3 & $<0.001$ & 146 \\
\hline Fatalist attitude & 12 & 11 & 15 & 22 & 6.0 & 3 & $<0.100$ & 133 \\
\hline Caste structure & 15 & 10 & 2 & 33 & 34.5 & 3 & $<0.001$ & 127 \\
\hline
\end{tabular}

Table 6 Prioritisation score of demands for forest products as management constraints as perceived by foresters

\begin{tabular}{lcrrrrr}
\hline Product demand as constraint & \multicolumn{2}{l}{ Rank $^{\mathrm{a}}$} & & & Score \\
\cline { 2 - 5 } & 1 & 2 & 3 & 4 & 5 & \\
\hline Timber distribution & 35 & 11 & 2 & 10 & 2 & 247 \\
Fodder & 16 & 19 & 17 & 5 & 1 & 218 \\
Fuelwood & 7 & 24 & 24 & 3 & 2 & 211 \\
Grazing areas & 2 & 3 & 12 & 36 & 7 & 137 \\
NWFPs & 0 & 3 & 4 & 7 & 46 & 84 \\
\hline
\end{tabular}

${ }^{\text {a }}$ Weights of 5, 4, 3, 2 and 1 are attached to ranks of 1,2,3, 4 and 5 respectively

Table 7 Responses of forestry staff about awareness among people about forest

\begin{tabular}{|c|c|c|c|c|c|c|}
\hline \multirow[t]{2}{*}{ Forest degradation issue } & \multicolumn{3}{|c|}{ Awareness among user groups } & \multicolumn{3}{|c|}{ Goodness of fit test } \\
\hline & $\begin{array}{l}\text { High } \\
3\end{array}$ & $\begin{array}{l}\text { Medium } \\
2\end{array}$ & $\begin{array}{l}\text { Low } \\
1\end{array}$ & $\chi^{2}$ & $d f$ & $P$ \\
\hline Level of awareness of forest degradation & $23(38.3 \%)$ & $22(36.7 \%)$ & $15(25 \%)$ & 21.8 & 3 & $<0.001$ \\
\hline Need for forest improvements & $23(38.3 \%)$ & $16(26.7 \%)$ & $21(35 \%)$ & 1.3 & 2 & $<0.500$ \\
\hline
\end{tabular}

perceived that there is high level of awareness of forest degradation amongst the people. A similar proportion (38.3\%) of the staff recognised a high level of awareness amongst the people about the need for forest improvements. 
Concerning forest laws and rules, chi-squared tests of goodness-of-fit shows that null hypotheses can be rejected in all cases (Table 8). This implies high consistency in opinions of forestry staff about change in forest laws and rules, revision of rates for timber under Timber Distribution grants, organisational discipline, support of top forestry hierarchy and project support for effective implementation of JFM. All respondents felt that there should be "changes in forest laws and rules by investing more legal powers in forestry staff' (ranked first) in order to deal with the implementation of JFM. This shows the traditional attitude of the foresters in getting the work done (including implementation of JFM), through creation of fear of punishment, still continues. 'Increase in TD rates' is the second most highly ranked factor from foresters' perspectives for effective JFM. About 95\% of respondents agreed that TD rates should be increased but opinion differed between increasing it marginally or linking it with the market value of timber. 'Support through project for some time until the JFM becomes internalised as a regular departmental activity' ranked third.

In that executive staff perform mainly the planning and supervision related to JFM, and front-line staff execute the field work related to JFM at forest division level, differences of opinions between these two levels about various aspects of JFM could be expected. The following hypotheses were investigated:

$\mathrm{H}_{0}$ : The opinions of executive staff and front-line forest functionaries about different aspects of JFM are independent.

$\mathrm{H}_{1}$ : The opinions are not independent.

The significant $\chi^{2}$ values support the view that there is an association between type of forestry staff (executive staff and front-line forestry staff) and each of the response variables except for 'poor fodder availability' (Table 9).

In-service training on JFM is found associated with the type of forestry staff which implies unequal distribution of in-service training between front-line and executive staff (Table 9). There were significant associations between JFM constraints (scarcity of land for plantations, illiteracy and communication gap) and type of forestry staff. The perceptions concerning awareness amongst the people

Table 8 Summary of responses forest laws and regulations, and statistical tests

\begin{tabular}{|c|c|c|c|c|c|c|c|}
\hline \multirow[t]{3}{*}{$\begin{array}{l}\text { Forest law and } \\
\text { regulation issues }\end{array}$} & \multicolumn{3}{|c|}{$\begin{array}{l}\text { Response } \\
\text { category }\end{array}$} & \multicolumn{3}{|c|}{ Goodness-of-fit } & \multirow[t]{3}{*}{ Score } \\
\hline & Yes & $\begin{array}{l}\text { Can't } \\
\text { say }\end{array}$ & No & \multirow[t]{2}{*}{$\chi^{2}$} & \multirow[t]{2}{*}{$d f$} & \multirow[t]{2}{*}{$P$} & \\
\hline & 3 & 2 & 1 & & & & \\
\hline $\begin{array}{l}\text { Change in forestry laws and rules (by vesting more legal } \\
\text { powers in forestry staff) }\end{array}$ & 60 & 0 & 0 & $\propto$ & 2 & $<0.001$ & 180 \\
\hline Increase in $\mathrm{TD}$ rates & 57 & 0 & 3 & 48.6 & 1 & $<0.001$ & 174 \\
\hline Support through project & 48 & 4 & 8 & 59.0 & 2 & $<0.001$ & 160 \\
\hline Support of top forestry hierarchy & 33 & 11 & 16 & 13.3 & 2 & $<0.001$ & 137 \\
\hline Erosion in discipline due to JFM & 5 & 19 & 36 & 22.8 & 2 & $<0.001$ & 89 \\
\hline
\end{tabular}


Table 9 Summary table of $\chi^{2}$ values of variables and their significance

\begin{tabular}{llccc}
\hline Aspects of JFM & Variable & $\chi^{2}$ & $d f$ & $P$ \\
\hline $\begin{array}{c}\text { Training/tours related } \\
\text { to JFM }\end{array}$ & Training & 10.2 & 3 & $<0.010$ \\
& Tour & 19 & 3 & $<0.010$ \\
Management & In-service training & 7.36 & 1 & $<0.006$ \\
constraints & Scarcity of land available for plantation & 9.59 & 3 & $<0.020$ \\
of JFM & Availability of grazing lands & 9.2 & 4 & $<0.050$ \\
& Poor fodder availability & 8.08 & 4 & $<0.080$ \\
& Illiteracy amongst JFM participants & 14.4 & 2 & $<0.001$ \\
& Communication gap (between divisional staff & 9.03 & 2 & $<0.010$ \\
& and top-hierarchy) & 10.2 & 2 & $<0.005$ \\
Awareness & Need for forest improvements & 7.1 & 2 & $<0.050$ \\
& Level of forest degradation & 8.92 & 1 & $<0.002$ \\
Forest Act and Rules & Laxity in Forest Act & 7.36 & 1 & $<0.006$ \\
& Increase in TD rates & 10.0 & 1 & $<0.001$
\end{tabular}

about 'forest degradation' and 'need for forest improvements' are also found to be associated with the type of the staff. All the aspects related to Forest Acts and Rules considered important for better JFM are also found to be associated with the kind of forestry staff.

\section{Discussion}

'Depletion of the forest resource' was regarded as the most important factor responsible for successful JFM from the foresters' perspectives. This implies that scarcity of resources to locals plays an important role in their motivation for participation in JFM. Consequently, JFM has comparatively higher potential of success in areas where forests are degraded. 'Availability of land for plantations' is identified as the second most important factor perceived for the success of JFM. This confirms the traditional bureaucratic belief of the foresters where they regard mere fulfilment of prescribed plantation targets as a dominant indicator of success of any forestry program (including JFM). 'Granted rights of forest use', 'generation of additional income from JFM implementation', 'alternative employment opportunities' and 'homogenous village structure' in that order are judged as factors that would result in success of JFM. 'Granted rights of forest use' as a factor implies a realisation amongst foresters of the need to ensure continuity of people's right to forest use to sustain their livelihoods. 'Generation of additional income from JFM implementation' and 'alternate employment opportunities' are found to be important factors because they reduce dependence on the forests, ensuring their better regeneration during JFM. 
'The communication gap' (lack of frequent interaction between field staff and top hierarchy of FD) was perceived as the most important reason for failure of JFM. This failure could arise from a communication gap leading to a lack of common understanding about the socio-economic and technical aspects of JFM between the two groups of foresters. Communication is hampered by the seemingly broad and often inconsistent nature of the central agency directives (unilateral top-down approaches). Physical distance (which hampers the frequency and depth of communication) and social distance (e.g., differences in the background and experience of top hierarchy and field staff of FD resulting in elitism and language barriers) also hamper communication. Often behavioural norms become established and act as a barrier to adequate communication between central and field staff. For the successful implementation of JFM, the emphasis should be to increase the interaction between field staff and the top hierarchy of foresters with respect to JFM to bridge this communication gap ${ }^{3}$. Improved communication is needed between senior officials and the field staff to appreciate the problems faced by front-line forest functionaries, especially forest guards. Many staff members are not aware of the provincial JFM resolution. Existing institutional mechanisms including range, division and state level groups (Fig. 1) could be used as an active forum for discussion of issues relating to JFM.

'Political interference' and 'Inter-village disputes' are also identified as important factors which could lead to failure of JFM. 'Political interference' in the form of threats of transfer or suspension appears to prevent FD staff from performing their duties conscientiously. This occurs when staff prevent excess removal of forest produce, issue damage reports, and perform duties in accordance with existing forest laws. Representations are made by the people to political leaders who in turn put pressure on higher officials of the FD to caution field staff against their 'arbitrary actions'. As a consequence of frequent transfers, problems relating to lack of understanding of human and natural resource endowments in villages and alienation are built into the administrative system. This may be attributed to the conflicting roles of policing of forest property, owing to existing old laws and rules on the one hand and facilitation of JFM on the other. This implies the existing laws and rules must be modified to reduce procedural rigidity to make them compatible with current policies for successful implementation of JFM.

The conflicting roles of forest regulation versus extension puts front-line forest functionaries in a bind regarding the procedures to be adopted for JFM. This is supported by the argument of Saxena (1995) that instability of tenure of officials has led to a lack of sense of involvement in the JFM program. It was argued that transfers have been used as instruments of rewards and punishment by political parties in power. The prospect of loss of identity, authority and control bothers both hierarchies of staff. There is no transparency in change involving transfers and in the public mind short tenure has been regarded as a stigma. There have been instances when staff members, after completion of training in JFM, have been able to obtain preferred posting because of suitable political connections thus affecting

\footnotetext{
${ }_{3}^{3}$ Rastogi (1995) also argued that differences in expectations of two hierarchies create the feeling of not being understood and mar the initiative or innovation on the part of staff.[0]
} 
immediate benefits of training. Therefore, it is implicit that the transfer and posting policy should match positions with skills of staff. Consequently, institutional reforms assume great importance as far as implementation and the future of JFM projects is concerned.

'Homogenous village structure (socio-economic)' was regarded as the least important factor for the failure of JFM. This was expected because homogeneity of village structure leads to convergence (lack of confrontation) of needs and interest for their involvement in JFM. Caste structure was the least important factor that could lead to failure of JFM because almost all castes within each village had similar forest resource use. This implies villages with homogenous social structure should be considered as a unit, rather than merely a group of adjoining villages, for successful implementation of JFM. Lack of women's participation was considered to be of low importance for possible failure of JFM because decision-making is traditionally considered as a men's domain.

Almost all households collect NWFPs for their own domestic use in the study area, and about $30 \%$ of the households are dependent on sale of NWFPs for supplementing household income. However, the forestry staff accorded it the lowest priority for management and regard 'timber distribution' as the main constraint for forest management because provision of timber in the form of TD rights at low prices (as a giffen good) could encourage uneconomic and inefficient use, and more demand leading to more deforestation.

The responses of forestry staff show that there are differences in the perspectives of executive and front-line forest functionaries about various aspects related to JFM. A majority wanted forestry laws to be amended by investing more legal powers to support JFM. This was because forestry staff continue to be biased towards bureaucratic attitudes and a policing role, the majority wanting forest protection to be supported by more stringent forest laws and rules. This could be further attributed to fear of loss of authority amongst the staff due to the increasing facilitating role in JFM. The majority opinion that timber distribution should take place through timber depots established for for this purpose and at higher price meant that the balance of power should favour the FD. The majority of the staff consider increasing the legal authority in dealing with people to be a better option, which indicates lack of inertia for change of functioning and management style, and implies that staff are still oriented towards their bureaucratic role. Thus, for successful implementation of JFM there is a need for change in attitude towards being a facilitator for implementation of JFM. This is supported by Rastogi (1995), who argued that there are inherent conflicts for the change of these attitudes because JFM requires service orientation through extension.

The primary aim of FD officials is to have power, authority, social standing, job security and facilities; the orientation as a facilitator is secondary. Gilmour and Fisher (1991) gave the reasons for tardiness in implementing change as that it can be difficult for government departments to give up power, status and control over budgetary and extra-budgetary resources and incomes that stem from their control over large forest areas. Furthermore, the FD continues to be responsible for regulatory functions and direct management of large parts of the forest estate. Understandably, internal confusion and tensions arise when these functions have to 
be combined with transferring control of parts of the forest estate to other groups or people, as in the case of JFM.

The extent of in-service training related to JFM is not equally distributed amongst field and executive staff. Informal discussions with some of forestry staff further revealed that JFM-related training and visits have been beneficial in understanding the socio-economic, administrative and silvicultural issues pertaining to JFM. It could be suggested that forestry institutions should modify their training curriculum in order to incorporate social skills and the changing silvicultural concepts of forest management. This indicates that the type of past training, now unsuitable for JFM, needs to be supplemented by retraining forest officials. The training of front-line forest functionaries, especially forest guards who are supposed to be ex officio member of institutions for JFM, needs particular attention. In-service training on social skills and JFM implementation could also be useful for supporting JFM.

\section{Conclusions}

The views of the foresters found in this study explain why foresters find implementation of JFM difficult-because they do not have sufficient knowledge and training on social systems and social skills for effective implementation of JFM. Many foresters do share their belief with the foresters of 1950s, that communities are heavily driven by their needs and degrade the forests. Further, foresters are unwilling to lose their authority by leaving behind their regulatory (bureaucratic ethos) functions in favour of social (facilitatory ethos) functions. This means that to achieve sustainable JFM much needs to be done in relation to foresters, to transform their attitudes, values and training systems with the consideration that social forces are central in the co-management paradigm, including for JFM. Further, this shift in the attitudes of forestry staff with regard to protection of forests 'from' people to protection 'with' people would require a change in the style and content of the FD activities.

Most provincial JFM orders contain detailed prescriptions for the membership norms and organisational structures of the local institutions eligible for participation in JFM and prescribe the 'forest guard' to be responsible for conducting meetings of 'the local institution' for taking various decisions on JFM. By contrast, both the government guidelines and the JFM orders neglect the need for organisational change in the FD to make their functioning compatible with JFM. The FD reserves the right to cancel the JFM agreement if the VFDC (institution) is considered to be violating any terms or conditions. If the FD fails to honour its own commitments, the villagers have no reciprocal rights to cancel the agreement or penalise the department. Thus strategies which would make the JFM participants and the FD more equally responsible to honour their commitments with respect to JFM would be pivotal for effective implementation of JFM.

Effective implementation of JFM would require reforming the unilateral hierarchical top-down bureaucratic flow of information and decision-making in favour of a bilateral one. There is a need for increasing interaction between field 
staff and the top hierarchy of the FD and for designing policies and measures to reduce political interference for effective JFM.

The study findings imply that the role of forestry staff as custodians of the forests should give way to one of managers charged with specific social objectives and who regard the villagers as an important asset and a resource for sustainable JFM. Despite multiple understandings of some key JFM issues, foresters being public servants, the state and community institutions should be devised and enforced in such a way that their behaviour is regulated and controlled, making them more accountable and responsive to, and driven by, changing interests, limitations and aspirations of the local people.

Acknowledgements The authors thank the Association of Commonwealth Universities of the United Kingdom for providing a Commonwealth Fellowship to support this study, and also the University of Aberdeen for providing necessary infrastructural facilities for conducting this study. The British Council also deserves special thanks for the administration of the Fellowship. Anonymous reviewer and the editor-in-chief of the journal also deserve special mention for their constructive and valuable suggestions.

\section{References}

Anant SK (1972) The changing concept of caste in India. Vikas Publications, London

Berkes F, George P, Preston RJ (1991) Co-management: the evolution in theory and practice of joint administration of living resources. Alternatives 18(2):12-18

Carlsson L, Berkes F (2005) Co-management: concepts and methodological implications. J Environ Manage 75:65-76

Dalal SS (1992) Forestry: past, present and future. In: Khosla PK (ed) Status of indian forestry: problems and perspectives. Indian Society of Tree Scientists, Solan, India, pp 15-25

Datta SK, Ray M (1996) Government forest service training in India: recommendations for change. Unasylva 47(4):44-47

Dhar SK (1994) Rehabilitation of degraded tropical watersheds with people's participation. Ambio 23(3):216-221

Dove MR (1992) Forester's belief about farmers: a priority for social science research in social forestry. Agroforest Syst 17(1):13-41

Falconer J (1987) Forestry extension: a review of the key issues. Social Forestry Network paper 4c, Overseas Development Institute, London

Gilmour DA, Fisher RJ (1991) Villagers, forests and foresters. Sahyogi Press, Kathmandu

GOHP (1993) H.P. Forest Statistics 1993. Department of forest farming and conservation, Himachal Pradesh, Shimla

Hobley M (1996) Participatory forestry: the process of change in India and Nepal, rural development forestry, study guide 3, Rural Development Forestry Network, Overseas Development Institute, London

Kumar S, Kant S (2005) Bureaucracy and new management paradigms: modeling foresters' perceptions regarding community-based forest management in India. Forest Policy Econ 7:651-669

Lundgren BO (1987) Institutional aspects of agroforestry research and development. In: Steppler HA, Nair PKR (eds) Agroforestry: a decade of development. ICRAF, Nairobi

Malhotra KC, Poffenberger M (1990) Forest regeneration through community protection: the West Bengal experience. In: Poffenberger M (ed) Forest management partnerships: regenerating India's forests. Ford Foundation, New Delhi

Matta J, Alavalapati J, Kerr J, Mercer E (2005) Agency perspectives on transition to participatory forest management: a case study from Tamil Nadu, India. Soc Nat Resour 18:859-870

Overseas Development Agenecy (ODA) (1994) Himachal Pradesh Forestry Project, vol I (Project Proposal Document) and vol II (Annexes). Overseas Development Agency, London

Poffenberger M (1990a) Forest management partnerships: regenerating India's forests, executive summary of the workshop on sustainable forestry, New Delhi. 10-12 September, 1990 
Poffenberger M (1990b) Facilitating change in forest bureaucracies. In: Poffenberger M (ed) Keepers of the forest. Kumarian Press, West Hartford

Pretty J (2003) Social capital and the collective management of resources. Science 303(12):1912-1914

Rastogi A (1995) Impact of culture on process of joint forest management in India. Ambio 24(40):253255

Reddy SB, Parikh JK, Srinivasan PV (1999) Plantation programmes through people's participation: a case study from India. Biomass Bioener 17(3):257-271

Saxena NC (1995) Forests, people and profit new equations for sustainability. Natraj Publishers, Dehradun, India

Saxena NC (2000) Research issues in forestry in India. Ind J Agric Econ 55(3):359-383

Shaikh MAH (2000) Forestry in the new millennium. Ind Forest 126(2):103-110

Sharma RA (1995) Participatory forest management in India. Ambio 24(2):131-133

Thomson J (1995) Participatory approaches in government bureaucracies: facilitating the process of institutional change. World Dev 23(9):1521-1554

Wee A-C, Jackson B (1994) Forest Beat: a starting point for integrating participatory, planning and budgeting and monitoring. Wasteland News X(1):52-60 